\title{
РАННЬОМОДЕРНА ФІЯОСОФІЯ
}

\section{Микола Симчич \\ ВЧЕННЯ ПРО НЕСКІНЧЕННІСТЬ У МОГИЛЯН- СЬКИХ ФІЛОСОФСЬКИХ КУРСАХ (XVII-XVIII СТ.): ДО ПОСТАНОВКИ ПРОБЛЕМИ}

Питанню про нескінченність (infinitum) традиційно присвячувався один з розділів філософських курсів, читаних у Києво-Могилянській академії (КМА) XVII-XVIII ст. Цей розділ стандартно викладався в курсі фізики в контексті інших питань, пов'язаних із третьою й четвертою книгами «Фізики» Аристотеля: рух (motus), неперервність (continuum), місце (ubi) і час (quando). Обсяг розділу про нескінченність невеликий і займає здебільшого 7-10 аркушів in quarto рукописного тексту.

Донині могилянське вчення про нескінченність не привертало особливої уваги дослідників ${ }^{1}$. У цій статті, на підставі аналізу 12 курсів $^{2}$, прочитаних від 1645 до 1751

(C) М. Симчич, 2018

${ }^{1}$ Вчення про нескінченність в могилянських курсах розглядають Валерія Нічик і Іван Огородник в розділі «Категории “конечное” и “бесконечное” в историии отечественноий философии», що увійшов у колективну монографію «Материалистическая диалектика. Конечное и бесконечное». Проте представлений тут розгляд дуже побіжний [Парнюк 1982: 72-76]. Крім того, цю тему зачіпає Ярослава Стратій в монографії «Проблемы натурфилософии в философской мысли Украины в XVII ст.», де в основному зосереджується на вченні про нескінченність у Інокентія Гізеля [Стратий 1981: 92-101]

До того ж, глава про нескінченність була перекладена українською у виданні філософських курсів Теофана Прокоповича [Прокопович 1980: 199-217] і Георгія Кониського [Кониський 1990: 109-130].

2 Це - курси:

1. Інокентій Гізель, Філос. курс 1645/46-1646/47 навч. років, Opus totius philosophiae, IP НБУВ, ф. 303, од. зб. 128, арк. 453-457.

2.Стефан Яворський, Філос. курс 1691/92-1692/93 навч. років, Agonium philosophicum..., IP НБУВ, ф. 8, од. зб. 60, арк. 305-314.

3. Інокентій Поповський, Філос. курс 1699/1700-1701/02 навч. років, Universa philosophia comentariis scholasticis illustrata... IP НБУВ, ф. 312, од. зб. 622/396С, арк. 360 зв.-367 зв.

4. Теофан Прокопович, Філос. курс 1707-1709 навч. років, Philosophia peripatetica juxta numerum quatuor facultatum quadripartita..., IР НБУВ, ф. 301, од. зб. П43, арк. 103 зв.-113 зв.

5. Сильвестр Піновський, Філос. курс 1711/12-1712/13 навч. років, [Sine titulo] IP НБУВ ф. 307, од. зб. 446, арк. 169-177.

6.Йосиф Волчанський, Філос. курс 1715/16-1716/17 навч. років, Philosophia tripartita doctrinam Aristotelis de rebus dialecticis, physicis compraehendens... IP НБУВ, ф. 301, од. зб. П44, с. 663-688.

7.Іларіон Левицький, Філос. курс 1719/20-1720/21 навч. років, Appia trita seu atrium scientiae philosophicae..., ІР НБУВ, ф. 301, од. зб. П45, арк. 316-325 зв.

8. Платон Малиновський, курс 1721/22-1722/23 навч. років, Olympia philosophica..., IP НБУВ, ф. 305, од. зб. 166, арк. 312 зв.-319 зв.

9.Амвросій Дубневич, Філос. курс 1727/28-1728/29 навч. років, Philosophia perypatetica..., IP НБУВ, ф. 307, од. зб. 452, арк. 171-186. 
року, я хочу коротко окреслити той спосіб, в який професори КМА розуміли нескінченність. У статті буде розглянуто три аспекти могилянського викладу вчення про нескінченність: його визначення, поділ і властивості. А також буде показано, як могилянці, проходячи ці три «канонічні» для схоластичного методу етапи, розв'язували важливі філософсько-теологічні проблеми.

Розгляд питання про нескінченність професори КМА за традиційною схемою починають 3 його визначення. Між ними немає особливих дебатів з цього приводу. Визначення, яке вони пропонують, звучить приблизно так: нескінченне є тоді, коли, приймаючи певну кількість послідовно, завжди щось залишається ${ }^{3}$. Таке визначення нескінченного приписують Аристотелю. Деякі професори ${ }^{4}$ дають чіткіше посилання - Третя книга «Фізики», текст $63^{5}$, що відповідає 207a6-8 за нумерацією Бекера. Однак впадає у вічі, що визначення в різних курсах, які мають бути цитатою з Аристотеля, попри змістовну схожість, не збігаються дослівно. У Таблиці 1. наведено кілька таких формулювань.

Таблиця 1

\begin{tabular}{|l|l|}
\hline Гізель & [Infinitum] est id, cujus semper est aliquid extra accipere. [арк. 453] \\
\hline Яворський & $\begin{array}{l}\text { [Infinitum] est illud, cujus semper est ultra accipere successive ac- } \\
\text { cipientibus. [apк. 305] }\end{array}$ \\
\hline Левицький & $\begin{array}{l}\text { [Infinitum] est id, cujus secundum quantitatem successive } \\
\text { accipientibus semper aliquid accipere extra se vel ultra se. [apк. 316] }\end{array}$ \\
\hline Малиновський & $\begin{array}{l}\text { [Infinitum] est id, cujus secundum quantitatem successive } \\
\text { accipientibus aliquid extra est. [apк. 312] }\end{array}$ \\
\hline Кулябка & $\begin{array}{l}\text { [Infinitum est] id, cujus secundum quantitatem accipiendibus sem- } \\
\text { per est aliquid accipere extra [apк. 598] }\end{array}$ \\
\hline
\end{tabular}

Виникає питання, чим пояснити відмінності у формулюванні. Щоб відповісти на це питання, поглянемо латинський переклад тексту «Фізики» Аристотеля, розміщений у досить популярному у той час Коїмбрійському коментарі до «Фізики» Аристотеля6 ${ }^{6}$ Однак тут це місце звучить ще більш відмінно (див. Таб. 2). Якщо поглянути

10. Сильвестр Кулябка, Філос. курс 1737/38-1738/39 навч. років, Cursus philosophicus ingenuis sapientiae amatoribus..., ІР НБУВ, ф. 301, од. зб. П50, арк. 597-608.

11. Георгій Кониський, Філос. курс 1747/48-1748/49 навч. років, Philosophia peripatetica juxta numerum quatuor facultatum quadirpartita... 1747-49. Российская государственная библиотека (Москва, Російська Федерація), ф. 152, од.зб. 130, арк. 113-118 зв.

12. Георгій Кониський, Філос. курс 1749/50-1750-51 навч. роки, Philosophia juxta numerum quatuor facultatum..., 1749-51. ІР НБУВ, ф. 301, од. зб. П51, С. 181-188.

Оскільки курс Георгія Кониського 1747-49 років практично дослівно збігається з курсом Теофана Прокоповича, у подальшому я буду брати до уваги тільки курс Прокоповича.

${ }^{3}$ Гізель 1645-47: арк. 453; Яворський 1691-93: арк. 305; Піновський 1711-13: арк. 169; Волчанський 1715-17: с. 663; Левицький 1719-21: арк. 316; Малиновський 1721-23: арк. 312 зв.; Дубневич 1727-29: арк. 171 зв.; Кулябка 1737-39: арк. 597 зв.

4 Яворський 1691-93: арк. 305; Левицький 1719-21: арк. 316; Малиновський 1721-23: арк. 312; Кулябка 1737-39: арк. 591 зв.

${ }^{5}$ Ранньомодерні видання «Фізики» Аристотеля, крім поділу на книги і глави, містили ще розподіл на дрібніші частини - textus, - що певною мірою полегшує пошук відповідного місця. Проте ідентифікація тогочасних цитат з Аристотеля має додаткові складнощі, оскільки поділ на глави не збігається зі сучасними виданнями.

6 Коїмбрійський коментар до творів Аристотеля, крім «Фізики» - «In octos libros Physicorum» (1591), містив «Parva naturalia» (1592), «De caelo» (1592), «In libros meteororum» (1592), «De generatione et corruptione» (1597), «De anima» (1598), «Tractatus de anima separata» (1598), «In universam logicam» (1604). Він був виконаний групою єзуїтів - професорів університету в місті Коїмбрі (Португалія) - на доручення генерала Товариства Ісусового Єроніма Надаля 1561 року 
ще один поширений у той час переклад «Фізики» зроблений Йоаном Агіропулом, то побачимо ще більшу відмінність у формулюванні (див. Таб. 2). Відштовхуючись від цього, наша проблема одержує повністю протилежну подобу: чому могилянські «цитати» настільки подібні між собою?

Відповідь, видається, дуже проста. Виявляється, могилянці трималися найстарішого перекладу «Фізики», зробленого ще у XII ст. Яковом з Венеції, відомого як translatio vetus (див. Таб. 2). А відмінності у формулюванні можна пояснити тим, що могилянські професори не вважали за доцільне повторювати цитований текст дослівно ${ }^{7}$.

Чи можна з цього зробити висновок про анахроністичність і непрофесійність могилянських курсів? Виявляється, представники другої схоластики, визначаючи нескінченність, часто наводили вищенаведену цитату Аристотеля і також у старому перекладі. I так само як і могилянці вони не сильно переймалися, щоб цитата звучала дослівно (див. Таб. 2). Виглядає, що академічна культура того часу не мала таких строгих вимог щодо цитування, як сучасна.

Таблиця 2

\begin{tabular}{|c|c|}
\hline Коїмбрійці & $\begin{array}{l}\text { Infinitum igitur id est, cujus qui ratione magnitudinis aliquid su- } \\
\text { munt, iis aliquid semper licet extra acciperere. [Commentariorum } \\
\text { 1625: p. 499-500 (lib. 3, cap. 7)] }\end{array}$ \\
\hline $\begin{array}{l}\text { Translatio Joane } \\
\text { Agiropulo }\end{array}$ & $\begin{array}{l}\text { Infinitum igitur id est cujus semper aliquid extra rationes quanti- } \\
\text { tatis accipi potest: cujus vero nihil est extra, id est perfectum ac to- } \\
\text { tum. [Aristoteles 1995: } 114 \text { ] }\end{array}$ \\
\hline $\begin{array}{l}\text { Translatio vetus } \\
\text { (Яків з Венеції) }\end{array}$ & $\begin{array}{l}\text { Infinitum quidem igitur hoc est cujus secundum quantitatem ac- } \\
\text { cipientibus semper aliquid est accipere extra. [Aristoteles 1990: } \\
\text { 128] }\end{array}$ \\
\hline Сжи Генгель & $\begin{array}{l}\text { Infinitum est id, cujus secundum quantitatem successive accipi- } \\
\text { entibus semper aliquid accipere extra est. [Gengell 1688-87: арк. } \\
123 \text { зв.] }\end{array}$ \\
\hline $\begin{array}{l}\text { Франсиско } \\
\text { Суареш }^{8}\end{array}$ & $\begin{array}{l}\text { Infinitum est id, a quo semper est aliquid ultra accipere. [Soares } \\
\text { 1651: } 232 \text { (Physica, trac. 4, disp. 2, sec. 1, num. 166)] }\end{array}$ \\
\hline $\begin{array}{l}\text { Бартоломео Мас- } \\
\text { трі }^{9}\end{array}$ & $\begin{array}{l}\text {...infintum quod sit cujus semper est aliquid extra accipere } \\
\text { [Mastri 1727: } 270 \text { (Pysica, Disp 10, num. 2)] }\end{array}$ \\
\hline Англ. переклад & $\begin{array}{l}\text { So, that is infinite, of which it is always possible to take some part } \\
\text { outside, when we take according to quantity. [Aristotle 1983: 16] }\end{array}$ \\
\hline Рос. переклад & $\begin{array}{l}\text { Итак, безконечное есть там, где, беря некоторое количесто, } \\
\text { всегда можна взять что-нибуть за ним. [Аристотель 1981: 119] }\end{array}$ \\
\hline
\end{tabular}

[Madeira 2006: 2]. Коментар містив текст Аристотеля грецькою і латинською мовою, порядкове тлумачення, а також розширене тлумачення філософських проблем, до яких відсилав коментований текст.

${ }^{7}$ Не можна виключати, що вони одержали цитату з других чи третіх рук, тобто переписали не 3 Аристотеля, а від інших авторів.

${ }^{8}$ Франциско Суареш [Francisco Soares] (1605-1659) - це португальський єзуїт, автор впливового чотиритомного філософського курсу. У могилянських курсах його найчастіше іменують Suarez junior [Суарес молодший], щоб відрізнити від іншого більш відомого єзуїтського філософа іспанця Франсиска Суареса [Francisco Suárez] (1548-1617).

${ }^{9}$ Мастрі, однак, критично ставиться до цього визначення [Mastri 1727: Т. 2, p. 270] 
Проте не всі могилянські професори, визначаючи нескінченність, вдавалися до цієї досить складної Аристотелевої дефініції. Так, Теофан Прокопович дає зовсім просте визначення: «Infinitum [...], ut patet ex nomine, est id, quod fine caret (... нескінченне, як видно 3 назви, $\epsilon$ те, що не має кінця)» [Прокопович 1707-09: арк. 103 зв.]. Проте Прокопович $є$ особливим тільки в могилянському контексті, а між іншими представниками другої схоластики неважко знайти тих, що визначають нескінченність точно таким самим чином і не повторюють дефініцію Аристотеля, наприклад, Педро Уртадо де Мендоса [Hurtado 1624, p 312 (Physica, disp. 13, sес. 1, par. 1)] і Родріго де Арpiяra [Arriaga 1639, p. 365 (Physica, disp. 13, sec. 1)].

Щодо видів нескінченності, то могилянські професори наводять кілька таких видів, які здебільшого виділені за дихотомічним поділом. Першим іде поділ на сутнісну нескінченність (infinitum secundum essentiam або infinitum simpliciter / simplex) і акцидентальну нескінченність (infinitum per accidens або infinitum secundum quid) ${ }^{10}$.

Як видно з самої назви, сутнісна нескінченність невіддільна від сутності того, кому вона притаманна. Існує єдине суще, що втілює таку нескінченність, - це Бог. Бог володіє нескінченністю необхідно і відповідно до всіх свої ознак. Тобто Бог має всі свої ознаки на найвищому ступені: він $є$ нескінченно добрий - всеблагий, нескінченно розумний - всезнаючий, має нескінченну силу - всемогутній, нескінченний у часі (або існує поза часом) - вічний, просторово нескінченний - всюдисущий тощо.

Акцидентальна нескінченність, крім того, що не притаманна комусь необхідно, відрізняється від сутнісної тим, що існує тільки в одному відношенні (in certo genere). Тобто відповідно до однієї своєї ознаки щось нескінченне, а відповідно до іншої - ні.

Загалом виділяють три види такої нескінченності. Перший, нескінченність множинноcтi (infinitum multitudinis aбо numeri) - коли число елементів є безмежним. Тобто існують якісь дискретні одиниці, і їхня кількість $є$ нескінченною. Другий вид нескінченності - це нескінченність протяжності або величини (infinitum extensionis aбo magnitudinis) - коли щось $€$ просторово нескінченним, тобто $є$ якийсь континуум, скажімо, пряма чи площина, і він простягається без кінця. Третій - це нескінченність інтенсивності (infinitum intensionis або qualitatis) - коли є певна якість найвищого ступеню.

Поділ на сутнісну і акцидентальну нескінченність, так само як і його підподіли, приймають усі могилянські професори ${ }^{11}$. Можливі лише деякі незначні варіації у способі пояснення та іменування деяких з цих видів нескінченності. Наприклад, хтось буде говорити про infinitum extensionis [Малиновський 1721-23: арк. 313], а хтось про infinitum magnitudinis [Кониський 1749-51: с. 181], а хтось вживає дві назви паралельно [Кулябка 1737-39: арк. 599], при цьому зі змісту викладу в усіх трьох випадках зрозуміло, що ідеться про один і той самий вид нескінченності.

Набагато суперечливішим є розрізнення між категорематичною (categorematicum) i синкатегорематичною (syncategorematicum) нескінченністю. Могилянці погоджуються, що категорематична нескінченність - це нескінченність, що актуально існує ${ }^{12}$. Нато-

${ }^{10}$ Гізель 1645-47: арк. 453 зв.; Яворський 1691-93: арк. 305 зв.; Прокопович 1707-09: арк. 103 зв.; Піновський 1711-13: арк. 169; Волчанський 1715-17: с. 663; Левицький 1719-21: арк. 316 зв.; Малиновський 1721-23: арк. 313; Дубневич 1727-29: арк. 172 зв.; Кулябка 1737-39: арк. 601.

11 Гізель 1645-47: арк. 453 зв.; Яворський 1691-93: арк. 305 зв.; Прокопович 1707-09: арк. 104; Піновський 1711-13: арк. 169; Левицький 1719-21: арк. 317; Малиновський 1721-23: арк. 313; Дубневич 1727-29: арк. 173; Кулябка 1737-39: арк. 599; Кониський 1749-51, с. 181.

12 «Cathegorematicum, quod componitur ex entibus actu existentibus et dicitur simpliciter infinitum» [Яворський 1691-93: арк. 305 зв.] 
мість синкатегорематична нескінченність не має актуального існування. Стефан Яворський, визначаючи цей тип нескінченності, пише, що ця нескінченність складається 3 актуальних скінченних сущих, сущих минулого, а також можливих сущих майбутнього i їхнє число не може бути зведеним до остаточного ${ }^{13}$. Що цікаво, Яворський ніде не вказує, що ідеться про потенційну нескінченність. Проте в інших могилянських професорів можна зустріти найменування цієї нескінченності як потенційної - infinitum potestate [Волчанський 1715-17: C. 663] або infinitum potentiâ [Прокопович 1707-09: арк. 104].

Розрізнення актуальної і потенційної нескінченності дуже вагоме для Аристотелівської філософії, і важливість цього питання для Аристотеля великою мірою випливає 3 контексту античної філософії. 3 одного боку, грецька філософія почала своє існування $з$ того, що філософи шукали першопринцип, а цей принцип міг бути наділений ознаками нескінченності. 3 іншого, роздумування про нескінченність призводило до чітких парадоксів. Всі чотири парадокси Зенона з Елеї про неможливість руху виникають через нездатність осмислити нескінченність [див. Sorabji 1983: 321-335]. Biзьмемо для прикладу парадокс про стрілу. Стріла має перелетіти стадіон, при цьому вона спочатку має перелетіти його половину, але перед цим - половину цієї половини, яка складається в свою чергу ще з половинок, і цей поділ іде до нескінченності. Та цілком очевидно, що стріла не може перетнути нескінченність.

Щоб розв'язати ці суперечності, Аристотель робить розрізнення між двома видами нескінченності: актуальною нескінченністю і потенційною нескінченністю. Стріла, перелітаючи стадіон, долає скінченну відстань, але потенційно цю відстань можна ділити до нескінченності. Тобто ця відстань актуально скінченна, а потенційно нескінченна. Ніде в світі не існує актуальної нескінченності, а от потенційна нескінченність - це цілком легітимний концепт [див. Sorabji 1983: 210-214]. Так, ми можемо говорити про нескінченну кількість натуральних чисел, але це тому, що ми завжди можемо їх збільшувати. Яке б велике число ми не взяли, завжди є можливість до нього додати, наприклад, одиницю.

Виходячи з цієї своєї теорії, Аристотель вважав, що світ $є$ просторово скінченним, проте часово нескінченним. До просторовості можна прикласти категорію актуальноӥ скінченності/нескінченності. Простір - це щось, що актуально існує. Оскільки актуальна нескічненність $€$ неприйнятною, світ є просторово скінеченний. Зовсім інша справа 3 часом. Час розвивається. Ми маємо світ зараз, він буде завтра, після завтра і т.д. Зміна світу в часі якоюсь мірою нагадує процес лічби. Скільки ми б не лічили, ми не можемо дійти до кінця. Так само світ не може дійти до якоїсь межі в часі - він $є$ потениійно нескінченним [див. Tiles 2004: 6-32].

Повне відкидання актуальної нескінченності є неприйнятним для християнства. Сутність Бога як абсолютного сущого характеризується через нескінченність. Тому тут схоластичні філософи мусили відійти від Аристотеля і визнати, що актуальна нескінченність існує, і вона притаманна Богові. Інше питання, чи може існувати актуальна нескінченність у створеному світі.

Оскільки могилянці виділяють три види акцидентального нескінченного (нескінченне множинності, величини і якості), то виникає питання, чи може кожне 3 них існувати у світі. У своєму досвіді ми ніколи не зустрічалися з жодним з них. Так, нам ніколи

13 «Aliud syncathegorematicum, quod componitur ex entitatibus aliquibus existentibus finitis, aliquibus jam praeteritis, alquibus vero possibilibus sibi superaddibilibus, ita ut in illis successive accipeindis numquam deveniri possit ad ultimum.» [Яворський 1691-93: арк. 305 зв.] 
не траплялася нескінченна колекція предметів, чи річ, яка простягається за якимось виміром до нескінченності. Тому могилянці, слідом за іншими схоластами того часу, одностайні, що відповідно до природного стану речей (еx natura rerum) акцидентальна нескінченність не може актуально існувати. Однак їх цікавить інше питання, чи Бог, оскільки всемогутній, може таку нескінченність створити. Наприклад, чи Бог міг би створити річ, яка би була нескінченно великою.

Тут могилянські професори розділяються на два табори. Одні - Йосиф Волчанський, Іларіон Левицький, Амвросій Дубневич, Сильвестр Кулябка - відкидають припущення, що Бог може створити актуальну нескінченність ${ }^{14}$. Інші їхні колеги - Інокентій Гізель, Стефан Яворський, Інокентій Поповський, Сильвестр Піновський, Платон Малиновський ${ }^{15}$ - схиляються до думки, що Бог може створити таку нескінченність.

Слід трохи детальніше подивитися, як наведені професори висвітлюють це питання. Хочу зокрема розглянути курс Стефана Яворського. Тут досить чітко стверджується про можливість категорематичної нескінченності у множинності речей:

Possibile est infinitum cathegorematicum in multitudine tam entium spiritualim, v.g. angelorum, animarum rationalium, quam corporum etiam nonpenetratorum. Ita Arriaga, Hurtadus, Vasques, Fassolus, Avicenna, Occamus ex antiquorum Plato, Phythagoras et plurimi recentiores, et meus venerandus professor, contra Suarez, Maurum, Valentiam, Complutenses ceterasque complures etc.» ${ }^{16}$ [Яворський 1691-93: арк. 307]. Можливим $\epsilon$ категорематичне нескінченне у множинності як щодо духовних сущих, наприклад, ангелів, розумних душ, так і тіл, також непроникних. Так [вважають] Арріяга, Уртадо, Васкес, Фасоло, Авіцена, Окам, з античних Платон, Піфагор і багато новіших, і мій шановний професор, проти Суареса, Маура, Валенсії, Комплютенців і інших численних.

Ця теза є досить інформативною. Вона вказує на дві речі. По-перше, свідчить, що питання про актуальне нескінченне викликало багато дебатів у тогочасній схоластичній філософіiі, і частина дуже славних на той час авторів, як Габрієль Васкес, Педро Уртадо де Мендоса, Родріго де Арріяга, були на стороні Яворського, а інші не менш впливові, зокрема Комплютенці, Грегоріо де Валенсіа і Франсиско Суарес, займали протилежну позицію. Про важливість цього питання свідчить дальший детальний аналіз аргументів і контраргументів щодо цієї тези на семи сторінках рукописного тексту. По-друге, до списку авторів, на яких спирається, Стефан Яворський долучає свого професора. Це не єдине місце в філософському курсі, де Яворський робить відсилку до свого «шанованого професора». При цьому у своєму курсі Яворський зберігає інтригу і залишає професора анонімним. Та розкриває карти Інокентій Поповський, що викладав філософію в КМА на кілька років пізніше, він твердить, що професором Яворського був о. Ян Янішевський, учень самого Яна Моравського [Поповський 1699-1702: арк. 602]. Янішевський викладав

${ }^{14}$ Волчанський 1715-17: с. 668; Левицький 1719-21: арк. 320; Дубневич 1727-29: арк. 180; Кулябка 1737-39: арк. 603 зв.

15 Гізель 1645-47: арк. 453 зв.-456; Яворський 1691-93: арк. 307; Піновський 1711-13: арк. 170v; Малиновський 1721-23: арк. 316.

${ }^{16}$ Цю тезу дослівно передає Сильвестр Піновськийюякий. При цьому Піновський знімає посилання і обмежується розпливчастим «est multorum contra plurimos» [Піновський 1711-13, арк. 171]. Загалом це характерно для Піновського, який часто скорочує довгі посилання Яворського. В цьому випадку може бути ще й окрема причина - Яворський посилається на свого професора. Зрозуміло, Піновський мусив тут якимсь чином переформатовувати таке посилання. Він вибрав простіший варіант - його зняти. 
філософію у різних єзуїтських колегіях Речі Посполитої, зокрема в Любліні в 1681-83 роках [Grzebień 1996: 238]. Там, найімовірніше, вчився в нього Стефан Яворський ${ }^{17}$.

У нашому питанні Яворський продовжує спадкоємність думки від свого учителя й долучається до певного напрямку в філософській традиції того часу. Проте не варто розуміти Стефана Яворського як просто ретранслятора поглядів свого учителя. 3 восьми мені відомих відсилок на «шановного професора» п’ ять $€$ запереченням поглядів останнього $^{18}$.

Інші два види акцидентальної нескінченності (нескінченність інтенсивності і протяжності) Яворський висвітлює більш побіжно. Він погоджується з можливістю існування нескінченності за інтенсивністю і наводить приклад температури, яка може мати один градус (gradus primus), але може мати і два градуси, і будь-який вищий градус ${ }^{19}$ [Яворський 1691-93, арк. 310]. Щодо нескінченності величини, то Яворський визнає можливість актуального існування такої нескінченності, проте з певним уточненням: щось може простягатися до нескінченності, але не в трьох вимірах. Нескінченне протяжності неможливе в усіх вимірах, тому що такий безмежно великий предмет закрив би весь простір, i тоді був би неможливим рух. Найімовірніше, побіжність викладу цих двох видів акцидентальної нескінченності пов'язана $з$ тим, що питання про їхнє можливе актуальне існування розглядається разом з нескінеченністю множинності. Як бачимо, могилянські професори або приймають можливість існування всіх трьох, або відкидають всі три. Немає випадків, коли би, наприклад, хтось приймав одну, а відкидав дві інші. Навіть в деяких курсах ці три питання розглядаються як одне [Дубневич 1727-29: арк. 180; Кулябка 1737-39: арк. 603 зв.].

Представники іншого табору могилянських професорів відкидали будь-яку актуальну нескінченність. Зокрема Сильвестр Кулябка чітко відкидає всі види категорематичної акцидентальної нескінченності:

Implicat omne infinitum categorematicum creatum tam in essentia, quam magnitudine, multitudine, intentisone, aut quacunque alia perfectione. Ita communiter Thomisatae, Scotistae et alii contra Nominales et Vasquez. [Кулябка 1737-39: арк. 603 зв.] Неможливе будь-яке категорематичне нескінченне між створіннями, як сутнісне, так і [нескінченне] величини, множинності, інтенсивності або будь-якої іншої досконалості. Так [вважають] томісти, скотисти і інші проти номіналістів і Васкеса.

Інші могилянські професори, які близькі за позицією до Кулябки, висловлюють свою думку більш м'яко. Наведу формулювання Іларіона Левицького щодо нескічненості множинності ${ }^{20}$ :

${ }^{17}$ Про те, що Стефан Яворський вчився у Люблінські єзуїтській колегії знаємо з біографії, зробленої Пилипом Терновським [Терновский 1864: 52]. У цій біографії робиться посилання на власноручні студентські рукописи Яворського під назвою «Oedipus aenigmaticam Aristotelis sphingem soluturus, seu compendiosa philosophiae mea manus scripta, ex opere manu scripto Philosophiae, quam audivi Leopolis et Lublini.». Ці рукописи на той момент зберігалися у ніжинському монастирі. Ймовірно, ідеться про Благовіщенський монастир у Ніжині. Яка доля цих рукописів після приходу радянської влади, мені не відомо.

18 Яворський не погоджується зі своїм професором: Яворський 1691-93: арк. 183 зв., 257 зв., 259 3в., 265, 270; і приймає думку останнього: Яворський 1691-93: арк. 275 зв., 307, 555 зв.

${ }^{19} \mathrm{He}$ ясно, які градуси тут мається на увазі, адже відомі зараз шкали вимірювання температури (Цельсій, Ференгейт, Кельвін), тоді ще не були винайдені.

20 Дуже подібно висловлюється Левицький і щодо інших видів акцидентальної категорематичної нескінченності [Левицький 1719-21: арк. 321 зв.]. 
Probabile est non esse possibile infinitum categorematicum in multitudine seu in numero. [Левицький 1719-21: арк. 320]. Найімовірніше, що не є можливим категорематичне нескінченне множинності чи числа.

Хоча позиція Левицького близька до позиції Кулябки, але вони відрізняються рівнем епістемологічної певності. Кулябка чітко пише, що актуальна нескінченність між створіннями неможлива, i його переконання в цьому є повним. Натомість Левицький проявляє менший рівень епістемологічної певності щодо цього. Він вводить свою тезу чеpeз фразу «probabile est...», що можна би було перекласти як «ймовірно, що...». Але думаю, такий варіант перекладу є хибним.

Щоби пояснити чому це так, варто вдатися до сучасної ймовірнісної епістемології. Людина може підтримувати чи не підтримувати певне судження з різною мірою певності (суб'єктивної ймовірності). Вона може щось приймати як цілком певне (безсумнівне) або відкидати його як повністю неможливе. Перше можна на шкалі певності позначити як 100 одиниць, а друге як - 0. Проте можливі і проміжні варіанти певності. Припустимо, 80 одиниць, коли вважає щось достатньо ймовірним, але не повністю певним, або 20 - майже неможливе, але існує певна ймовірність, що це не так. Крім того, існує суб'єктивна ймовірність у 50 одиниць, що виражає неможливість визначитися, чи підтримувати це судження, чи ні.

У випадку з Іларіоном Левицьким з контексту обговорення видно, що загалом він підтримує неможливість актуальної нескінченність у створеному світі. Проте допускає певні сумніви 3 приводу цього. Тому його суб'єктивна ймовірність є досить високою, але не повною (можна оцінити десь в 80-90 одиниць), що виражено через фразу «probabile est». Українську фразу «ймовірно, що», можна інтерпретувати по-різному це може бути як 80-90, так і 50. Щоб уникнути такої інтерпретації, вважаю за доречне перекласти «найімовірніше, що».

Що цікаво, між могилянськими професорами, $є$ такі, які в цьому питанні приймають імовірність у 50 одиниць. Це - Теофан Прокопович. Прокопович, як і інші професори, вважає, що Бог представляє сутнісну актуальну нескінченність, а актуальна нескінченність між створіннями неможлива відповідно до природного порядку речей. Проте він відмовляється дати відповідь на питання, чи може Бог створити актуальну нескінченність. Він детально розглядає аргументи і контраргументи обох таборів і приходить до висновку, що невідомо, хто з них правий. I взагалі людський розум не здатний пізнати, чи Бог може створити актуальну нескінченність у створеному світі чи ні [Прокопович 1707-09: арк. 106 зв.-113 зв.]. Така позиція Прокоповича є незвичною в могилянському контексті, але, дуже ймовірно, і в ширшому контексті другої схоластики. Прокопович не відкидає це питання як малозначуще, а висвітлює його дуже детально, щоб врешті прийти до скептичного висновку. Виглядає, що відкинути цю філософсько-теологічну проблему він не міг, бо вона була надто актуальною для схоластичної філософії того часу.

Але не тільки могилянські професори розійшлися між собою щодо цього питання. Як бачимо з попередньо наведених цитат Яворського і Кулябки, одні схоластичні авторитети підтримували позицію про засадничу неможливість актуальної нескінченності (томісти, скотисти, Коїмбрійці, Грегоріо де Валенсіа і Франсиско Суарес), а інші допускали, що хоча природнім чином така нескінченність не може виникнути, Бог, 
будучи всемогутнім, може їі створити (номіналісти, Габрієль Васкес, Педро Уртадо де Мендоса, Родріго де Арріяга) ${ }^{21}$.

3 викладеної дискусії можна зробити такий попередній висновок. Аристотелізм принципово не приймав актуальної нескінченності. Деякі схоласти, хоча, звісно, приймають сутнісну нескінченність Бога, намагаються засадничо триматися Аристотеля i відкидають можливість існування актуальної нескінченності у створеному світі. Так, Тома Аквінський, розглядаючи питання про нескінченність у «Сумі теології», чітко зазначає, що тільки Бог є актуально нескінченним, ніщо інше зі створеного не може бути актуально нескінченним ні щодо величини, ні щодо числа (STh, Ia, q.7). Бог не може створити таку нескінченність не тому, що не всемогутній, але тому що така нескінченність $є$ принципово неможливою. Це все одно, що створити круглий квадрат. Це тому, що Бог у своїй творчій діяльності підпорядкововується законам світу, які сам створив. Якби цих законів не існувало, світ би не існував. Таким чином, ці закони існують реально. Тому нічого дивно, що ці філософи - скотисти і томісти - $\epsilon$ реалістами в розв'язанні питання про універсалії. Виглядає, що номіналістично орієнтовані філософи (у другій схоластиці - це Педро Уртадо де Мендоса і Родріго Арріяга) ${ }^{22}$ менше звертають увагу на закони природи. Для них Бог не має обмежень у своїй діяльності, тому може створити навіть те, що за природнього стану речей неможливе.

Дискусії з приводу актуальної нескінченності позначилися і на інших питаннях, які обговорюють могилянські професори. Ще одним пунктом у розділі про нескінченність $\epsilon$ питання про їі властивості. У переліку властивостей привертає увагу одна, яка викликає дискусії між професорами. Так, деякі професори, наприклад, Стефан Яворський твердять, що одне нескінченне може бути більшим за інше. Яворський підкріплює свою позицію таким прикладом. Якщо взяти нескінченну кількість людей, то кількість їх рук буде в два рази більшою. Отже нескінченність рук $є$ у два рази більшою від нескінченності людей. Проте те і те є нескінченністю. Таким чином, одна нескінченність $є$ більша від іншої. 3 таким розв'язанням не погоджується Іларіон Левицький. Він вважає, що поняття більшого і меншого нескінченного приципово суперечливе, тому що може бути тільки одна нескінченність. Тому, розв'язуючи питання про нескінченну кількість людей і їхніх рук, він приходить до висновку, що така нескінченність не може існувати.

Це питання можна би було розв'язати відносно просто, якщо взяти на озброєння розрізненням між актуальною і потенційною нескінченністю. Актуальна нескінченність не може бути більшою чи меншою, тому що існує тільки одна така нескінченність - це Бог. Проте потенційна нескінченність може бути більшою і меншою. Візьмемо до прикладу ряди чисел, кількість парних чисел буде в два рази меншою, ніж кількість цілих чисел, проте та і та множина є нескінченною.

Оскільки Левицький не приймає актуальної нескінченності, він може відкинути і розрізнення між більшою і меншою нескінченністю. Яворський допускає існування актуальної нескінченності, тому також приймає, що вона може бути більшою і меншою.

${ }^{21}$ Коректність цього посилання вдалося відслідкувати по таких курсах: Коїмбрійці [Commentrium 1625: 522 (lib. 3, cap. 5-8, q. 2, art. 3)]; Утрадо де Мендоса [Hurtado 1624: 313 (Physica, disp. 13, sec. 1, par. 10)], Арріяга [Arriaga 1639: 269 (Physica, disp. 13, sec. 4, num. 32)].

22 Виглядає, цю теорію підтримував і найбільшвідомий середньовічний номіналіст Вільям Окам. Посилання на нього зустрічаємо в представників обох таборів [Commentrium 1625: 518 (lib. 3, cap. 5-8, q. 2, art. 1); Hurtado 1624: 313 (Physica, disp. 13, sec. 1, par. 10)]. Проте розв'язання цього питання Окамом потребує додаткового дослідження. 
Розглянутий у статті фрагмент філософського курсу зовсім невеликий за обсягом займає здебільшого 2-3\% курсу фізики або 1-2\% тексту всього філософського курсу, та зміст цього тесту дає значні філософські і не тільки філософські відсилки. Цей текст має метафізичний, епістемологічний, теологічний, фізичний і математичний зрізи.

Дискусія щодо актуальної і потенційної нескінченності у створеному світі має чітке теологічне підгрунтя і веде до питання про Божу всемогутність. Але з іншого боку, вона вказує на метафізичне розрізнення реалізму і антиреалізму ${ }^{23}$. Філософи реалістичного спрямування схильні вважати, що закони світу - фізичні, логічні, моральні - існують об'єктивно, і навіть сам Бог не може їх змінити. Філософи, яких умовно можна маркувати як «антиреалісти», скептичні щодо об'єктивності законів дійсності. Така метафізична позиція дає більше простору для Божої всемогутності взагалі, і у питанні нескінченності зокрема. Могилянське розв'язання цього складного питання показує, що, крім метафізичного, $є$ ще й епістемологічний вимір. Це питання ставить у ступор людський розум, і людина, яка намагається на нього відповісти, часто не має відчуття впевненості у знайденому розв'язку. Тому позиції могилянських авторів, на мою думку, варто інтерпретувати, виходячи 3 епістемологічної концепції суб'єктивної ймовірності ${ }^{24}$. Епістемологія не представлена експліцитно в могилянських курсах, і їхні епістемологічні погляди можна реконструювати, виходячи з того, як вони розв'язували різні дотичні питання. При цьому треба бути дуже обережним, щоб не допустити анахронізму.

Питання нескінченності відіграє важливу роль у математиці і в фізиці. В той самий час, коли могилянці викладали свої курси, Ісак Ньютон і Готфрід Вільгельм Ляйбніц розробляють теорію диференційного і інтегрального числення, яка передбачає операції з нескінченностями. Нескінченність поступово одержує легітимне місце в математичному дискурсі. Питання про те, чи може існувати більше і менше нескінченне, турбують не тільки могилянських авторів. Але чітке математичне розв'язання цього питання було запропоноване через століття Георгом Кантором. Потребує дальшого дослідження питання наскільки математичні дискусії того часу впливали на могилянське вчення про нескінченність. Та дослідження цього питання потрібно проводити, беручи до уваги наступний розділ могилянських курсів - про безперервне (continuum).

Аналіз окремо взятого фрагменту філософського курсу може проливати світло також не деякі методологічні аспекти творення могилянських курсів. На прикладі аналізу дефініції нескінченного можна побачити, на які тексти спиралися могилянські професори й інші представники другої схоластики, та яка була академічна культура того часу, зокрема щодо сприйняття чужого тексту. Проте робити більш загальні висновки можна буде лише після того, як буде взято до уваги більшу кількість схожих випадків.

${ }^{23}$ Розрізнення реалізму і антиреалізму запропонував у сучасній філософії Майкл Даміт. Тут він пов'язав номіналізм щодо універсалій та відкидання можливості погляду на світ «очима Бога» в одне ціле [Dummett 2001].

${ }^{24}$ У сучасній епістемології $€$ багато дискусій щодо можливості приймати певне судження з різним рівнем певності, навіть існує окрема піддисципліна - Бейзівська епістемологія (Bayesian epistemology) [Hajek, Hartmann 2010] 


\section{СПИСОК ЛІТЕРАТУРИ}

Архівні матеріали

Волчанський, Йосиф (1715-17). Philosophia tripartita doctrinam Aristotelis de rebus dialecticis, physicis compraehendens... [Філософський курс]. Інститут рукопису (ф. 301, од. зб. П44). Національна бібліотека України ім. В.І. Вернадського (далі - НБУВ), Київ.

Гізель, Інокентій (1645-47). Opus totius philosophiae. [Філософський курс]. Інститут рукопису (ф. 303, од. зб. 128). НБУВ, Київ.

Дубневич, Амвросій (1727-29), Philosophia perypatetica..., [Філософський курс] Інститут рукопису (ф. 307, од. зб. 452). НБУВ, Київ.

Кониський, Георгій (1747-49). Philosophia peripatetica juxta numerum quatuor facultatum quadirpartita. [Філософський курс]. Отдел рукописей (ф. 152, ед.хр. 130,). Российская государственная библиотека, Москва.

Кониський, Георгій (1749-51). Philosophia juxta numerum quatuor facultatum... [Філософський курс]. Інститут рукопису (ф. 301, од. зб. П51). НБУВ, Київ.

Кулябка, Сильвестр (1737-39). Cursus philosophicus ingenui sapientiae amatoribus... [Філософський курс]. Інститут рукопису (ф. 301, од. зб. 50, арк. 1-820v). НБУВ, Київ.

Левицький, Іларіон (1719-21). Appia trita seu atrium scientiae philosophicae... - [Філософський курс]. Інститут рукопису (ф. 301, од. зб. П45). НБУВ, Київ.

Малиновський, Платон (1721-23). Olympia philosophica ad cursum biennalem... [Філософський курс]. Інститут рукопису (ф. 305, од. зб. 166). НБУВ, Київ.

Піновський, Сильвестр (1713-15). Disputationes philosophiae in Collegio Kievomohilaeano Roxolano... [Філософський курс]. Інститут рукопису (ф. 307, од. зб. 446). НБУВ, Київ.

Поповський, Інокентій (1699-1702). Universa philosophia comentariis scholasticis illustrata... [Філософський курс]. Інститут рукопису (ф. 312, од. зб. 622). НБУВ, Київ.

Прокопович, Теофан (1707-09). Philosophia peripatetica juxta numerum quatuor facultatum quadripertita... [Філософський курс]. Інститут рукопису (ф. 301, од. зб. П43). НБУВ, Київ.

Яворський, Стефан (1691-93). Agonium philosophicum in arena gymnadis... [Філософський курс]. Інститут рукопису (ф. 8, од. зб. 60). НБУВ, Київ.

Gengell, J. (1688-89) Philosophia naturalis seu physica disputationibus illustrata Anno 1688 die 7 Februarii inchoata Leopoli sub Reverendo Patre Georgio Gengell [Філософський курс] Інститут рукопису (ф. 306, од.зб. 91). НБУВ, Київ.

Друковані праиі

Аристотель. (1981). Физика. In Аристотель, Соч. в 4-x mm. (Т. 3). Москва: Наука.

Кониський, Г. (1990). Філософія природи або фізика. In Г. Кониський, Філософські твори у 2-х томах (Т. 2, сс. 5-507). Київ: Наукова думка.

Парнюк, М. А. (Ред.) (1982) Материалистическая диалектика. Конечное и бесконечное. Киев: Наукова думка.

Прокопович, Ф. (1980). Натурфілософія, або фізика. In Ф. Прокопович, Філософські твори в трьох томах (Т. 2, сс. 113-502). Київ: Наукова думка.

Стратий, Я. М. (1982). Проблемы натурфилософии в философской мыслли Украины ХVII в. Киев: Наукова думка.

Терновский, Ф. (1864). М[итрополит] Стефан Яворский (Биографический очерк). Tpуды Киевской Духовной Академии, (1), 36-70.

Aristoteles. (1990). Physica: Translatio vetus. In F. Bossier, J. Brams (Eds.), Aristoteles Latinus (Vol. VII.1). Leiden, \& New York: Brill.

Aristoteles. (1995). Aristoteles latine interpretibus variis. München: Wilhelm Fink.

Aristotle. (1983). Physics, books III and IV. (E. Hussey, Trans.). Oxford: UP.

Arriaga, R. de. (1639). Curus philosophicus. Parisii: Apud Iacobum Quesnel. 
Conimbriceneses. (1625). Commentariorum Collegii Conimbricensi Societatis Jesu In Octo Libros Physicorum Aristotelis Stagiritae (Pars 1). Coloniae: Sumptibus Haeredum Lazari Zetzneri.

Dummett, M. (2001). Realism. In: M. J. Loux (Ed.). Metaphysics: Contemporary Readings (pp. 459-479). London, \& New York: Routledge.

Grzebień, L. (Ed.). (1996). Janiszewski. In: Encyklopedia wiedzy o jezuitach na ziemiach Polski i Litwy 1564-1995 (p. 238). Kraków: Wyższa Szkoła Filozoficzno-Pedagogiczna "Ignatianum”, \& Wydawn. WAM.

Hajek, A., \& Hartmann, S. (2010). Bayesiam Epistemology. In: J. Dancy, E. Sosa,, \& M. Steup. (Eds.). A Companion to Epistemology (pp. 93-105). Chichester, West Sussex, U.K.; Malden, Mass.: Wiley-Blackwell.

Hurtado de Mendoza, P. (1624). Universa philosophia... Lugduni: sumpt. Ludouici Prost, haeredis Roville.

Madeira, J. (2006). Pedro da Fonseca's Isagoge Philosophica and the Predicables from Boethius to the Lovanienses. Doctoral thesis Katholieke Universiteit Leuven.

Mastri, B., \& Belluti, B. (1727). Philosophiae ad mentem Scoti cursus integer (T. 2.). Venetiis: Pezzana.

Soares, F. (1651). Cursus philosophicus in quatuor tomos distributus. (T. 2.). Conimbrigae: Typis P. Craesbeeck.

Sorabji, R. (1983). Time, Creation and the Continuum: Theories in Antiquity and the Early Middle Ages. London: Duckworth.

Tiles, M. (2004).The Philosophy of Set Theory: An Historical Introduction to Cantor's Paradise. Mineola, NY: Dover.

Одержано 15.07.2018

\section{REFERENCES}

Archival sources

Dubnevych, Amvrosii (1727-29) Philosophia peripatetica... [Philosophical course]. The Institute of Manuscripts (fonds 307, item 452). Vernadsky National Library of Ukraine (VNLU), Kyiv.

Gengell, Jerzy. (1687-89) Philosophia naturalis seu physica disputationibus illustrata Anno 1688 die 7 Februarii inchoata Leopoli sub Reverendo Patre Georgio Gengell Philosophical course]. The Institute of Manuscripts (fonds 306, item 91). VNLU, Kyiv.

Gizel, Inokentiy (1645-47). Opus totius philosophiae. [Philosophical course]. The Institute of Manuscripts (fonds 303, item 128). VNLU, Kyiv.

Konyskyi, Georgiy (1747-49). Philosophia peripatetica juxta numerum quatuor facultatum quadirpartita. [Philosophical course]. The department of manuscripts (fonds 152, item 130). Russian State Library, Moscow.

Konyskyi, Georgiy (1749-51). Philosophia juxta numerum quatuor facultatum... [Philosophical course]. The Institute of Manuscripts (fonds 301, Petrov's Catalogue, item 51). VNLU, Kyiv.

Kulabka, Sylvestr (1737-39). Cursus philosophicus ingenui sapientiae amatoribus... [Philosophical course]. The Institute of Manuscripts (fonds 301, Petrov's Catalogue, item 50). VNLU, Kyiv.

Levytskyi, Ilarion (1719-21). Appia trita seu atrium scientiae philosophicae... [Philosophical course]. The Institute of Manuscripts (fonds 301, Petrov’s Catalogue, item 45). VNLU, Kyiv.

Malynovskyi, Platon (1721-23). Olympia philosophica ad cursum biennalem... [Philosophical course]. The Institute of Manuscripts (fonds 305, item 166). VNLU, Kyiv.

Pinovskyi, Sylvestr (1713-15). Disputationes philosophiae in Collegio Kievomohilaeano Roxolano... [Philosophical course]. The Institute of Manuscripts (fonds 307, item 446). VNLU, Kyiv.

Popovskyi, Inokentiy (1699-1702). Universa philosophia comentariis scholasticis illustrata... [Philosophical course]. The Institute of Manuscripts (fonds 312, item 622). VNLU, Kyiv.

Prokopovych, Teofan (1707-09). Philosophia peripatetica juxta numerum quatuor facultatum quadripertita... [Philosophical course]. The Institute of Manuscripts (fonds 301, Petrov's Catalogue, item 43). VNLU, Kyiv. 
Volchanskyi, Yosyf (1715-17). Philosophia tripartita doctrinam Aristotelis de rebus dialecticis, physicis compraehendens... [Philosophical course]. The Institute of Manuscripts (fonds 301, Petrov's Catalogue, item 44). VNLU, Kyiv.

Yavorskyi, Stefan (1691-93). Agonium philosophicum in arena gymnadis... [Philosophical course]. The Institute of Manuscripts (fonds 8, item 60). VNLU, Kyiv.

Printed works

Aristoteles. (1990). Physica: Translatio vetus. In F. Bossier, J. Brams (Eds.), Aristoteles Latinus (Vol. VII.1). Leiden, \& New York: Brill.

Aristoteles. (1995). Aristoteles latine interpretibus variis. München: Wilhelm Fink.

Aristotle. (1983). Physics, books III and IV. (E. Hussey, Trans.). Oxford: UP.

Arriaga, R. de. (1639). Curus philosophicus. Parisii: Apud Iacobum Quesnel.

Conimbriceneses. (1625). Commentariorum Collegii Conimbricensi Societatis Jesu In Octo Libros Physicorum Aristotelis Stagiritae (Pars 1). Coloniae: Sumptibus Haeredum Lazari Zetzneri.

Dummett, M. (2001). Realism. In: M. J. Loux (Ed.). Metaphysics: Contemporary Readings (pp. 459-479). London, \& New York: Routledge.

Grzebień, L. (Ed.). (1996). Janiszewski. In: Encyklopedia wiedzy o jezuitach na ziemiach Polski i Litwy 1564-1995 (p. 238). Kraków: Wyższa Szkoła Filozoficzno-Pedagogiczna "Ignatianum”, \& Wydawn. WAM.

Hajek, A., \& Hartmann, S. (2010). Bayesiam Epistemology. In: J. Dancy, E. Sosa,, \& M. Steup. (Eds.). A Companion to Epistemology (pp. 93-105). Chichester, West Sussex, U.K.; Malden, Mass.: WileyBlackwell.

Hurtado de Mendoza, P. (1624). Universa philosophia... Lugduni: sumpt. Ludouici Prost, haeredis Roville. Konyskyi, G. (1990). The Philosophy of Nature or Physics. [In Ukrainian]. In: Konyskyi G. Philosophical Works in Two Volumes (Vol. 2). Kyiv: Naukova Dumka.

Madeira, J. (2006). Pedro da Fonseca's Isagoge Philosophica and the Predicables from Boethius to the Lovanienses. Doctoral thesis Katholieke Universiteit Leuven.

Mastri, B., \& Belluti, B. (1727). Philosophiae ad mentem Scoti cursus integer (T. 2.). Venetiis: Pezzana.

Parniuk, M. A. (Ed.) (1982). Materialistic Dialectics. Finite and Infinite. [In Russian]. Kyiv: Naukova Dumka.

Prokopovych, F. (1980). The Philosophy of Nature or Physics. [In Ukrainian]. In: Prokopovych, F. Philosophical Works in Three Volumes (Vol. 2). Kyiv: Naukova Dumka.

Soares, F. (1651). Cursus philosophicus in quatuor tomos distributus. (T. 2.). Conimbrigae: Typis P. Craesbeeck.

Sorabji, R. (1983). Time, Creation and the Continuum: Theories in Antiquity and the Early Middle Ages. London: Duckworth.

Stratii, Y. M. (1982). The Problems of the Philosophy of Nature in the Philosophical Thought of Ukraine in the $17^{\text {th }}$ Century. [In Russian]. Kyiv: Naukova Dumka.

Ternovskii, F. (1864). "M[etropolitan] Stefan Yavorskii (A biographical essay). [In Russian]. Trudy Kievskoi Dukhovnoi Adademii, (1), 36-70.

Tiles, M. (2004).The Philosophy of Set Theory: An Historical Introduction to Cantor's Paradise. Mineola, NY: Dover.

Received 15.07.2018

\section{Mykola Symchych}

\section{The Problem of Infinity in Kyiv-Mohylian Philosophical Courses (the $17^{\text {th }}$ $18^{\text {th }}$ centuries): A Preliminary Study}

The article analyses the explication of the infinity in the philosophical courses taught at KyivMohyla Academy at the 17th and 18th centuries. It examines 12 philosophical courses - since 1645 
(the course by Inokentii Gizel) until 1751 (the course by Georgii Konyskyi). In general, all the professors, as well as other scholastic philosophers, agree that categorematic infinity exists only in God, but syncategorematic is present in the created world. Regarding the question of whether God, being omnipotent, can create a categorematic infinity in the world, the Mogilyans are divided into several camps: (1) Inokentii Gizel, Stefan Yavorskyi, Inokentii Popovskyi, Sylvestr Pinovskyi, Platon Malynovskyi gave a positive answer to the question; (2) Yosyf Volchanskyi, Ilarion Levytskyi, Amvrosii Dubnevych, Sylvestr Kulabka believed that this kind of infinity is in principle impossible, hence God cannot create it; (3) Theophan Prokopovych and Georgii Konyskyi took a skeptical stand and considered that the human mind as such could not solve this problem. The article analyses which arguments were offered by each camp, and gives essential suggestion: most probably, Mohylian philosophers who supported the possibility of actual infinity in the created world were influenced by nominalistically oriented Jesuit philosophers, like Pedro Hurtado de Mendoza and Rodrigo Arriaga. The other Mohylians backed a more traditional idea, supported by Thomas Aquinas, that only one actual infinity can exist and it is God.

\section{Микола Симчич}

\section{Вчення про нескінченність у могилянських філософських курсах (XVII- XVIII ст.): до постановки проблеми}

У статті досліджуються тлумачення нескінченності у філософських курсах, читаних у Києво-Могилянській академії XVII-XVIII ст. Було проаналізовано розділ про нескінченність у 12 могилянських курсах від 1645 (курс Інокентія Гізеля) до 1751 (курс Георгія Кониського). Загалом могилянці, як і інші схоластичні філософи, погоджуються, що актуальна нескінченність існує тільки в Бозі, а потенційна представлена у світі. Щодо питання про спроможність всемогутнього Бога створити категорематичну нескінченність у світі могилянці поділяються на кілька таборів: (1) Інокентій Гізель, Стефан Яворський, Інокентій Поповський, Сильвестр Піновський, Платон Малиновський вважали, що Бог на це спроможний; (2) Йосиф Волчанський, Іларіон Левицький, Амвросій Дубневич, Сильвестр Кулябка стверджували, що актуальна нескінченність у створеному світі принципово неможлива, тому Бог іiї не може створити; (3) Теофан Прокопович і Георгій Кониський посідають скептичну позицію, вважаючи, людський розум нездатним відповісти на це питання. У статті аналізуються аргументи кожного з таборів та висувається таке припущення: найімовірніше, могилянські професори, що визнавали можливість актуальної нескінченності у створеному світі, перебували під впливом номіналістично орієнтованих єзуїтських філософів, як от Педро Уртадо де Мендоса і Родріго Арріяга. Інші могилянці приймали більш традиційну ідею Томи Аквінського про існування тільки однієї актуальної нескінченності, себто Бога.

Mykola Symchych, PhD in philosophy, a researcher at the Institute of Philosophy of the National Academy of Sciences of Ukraine (Kyiv).

Микола Симчич, к. філос. н., науковий співробітник Інституту філософії ім. Г.С. Сковороди НАН України.

e-mail: msymchych@gmail.com 